\begin{tabular}{c} 
Volume and Issues Obtainable at Center for Sustainability Research and Consultancy \\
Journal of Accounting and Finance in Emerging Economies \\
ISSN: 2519-0318 ISSN (E) 2518-8488 \\
Volume 5: Issue 1 June 2018 \\
JSRᄃ \\
Journal homepage: $\underline{\text { www.publishing.globalcsrc.org/jafee }}$ \\
\hline
\end{tabular}

\title{
The Impact of International Financial Reporting Standards (IFRS) on Accounting Quality in Malaysia
}

\author{
${ }^{1}$ Ooi Chee Keong, ${ }^{2}$ Lee Siew Pengb, ${ }^{3}$ Lim Wan Lengc \\ ${ }^{1}$ Faculty of Accountancy and Management (FAM), Universiti Tunku Abdul Rahman (UTAR), Malaysia. \\ Email adress: ckooi@utar.edu.my \\ ${ }^{2}$ Faculty of Accountancy and Management (FAM), Universiti Tunku Abdul Rahman (UTAR), Malaysia. \\ Email adress: leesp@utar.edu.my \\ ${ }^{3}$ Faculty of Accountancy and Management (FAM), Universiti Tunku Abdul Rahman (UTAR), Malaysia. \\ Email adress: limwl@utar.edu.my
}

\begin{tabular}{l} 
ARTICLE DETAILS \\
\hline History \\
Revised format: May 2019 \\
Available Online: June 2019
\end{tabular}

\section{Keywords}

Malaysian Financial Reporting

Standards, Accounting Quality,

Earnings Management, Malaysia

JEL Classification:

$C 1, C 2, D 4, F 31, F 37$

\begin{abstract}
There are two objectives of this study, first,it is to examine and compare the accounting quality in pre-and post-implementations IFRS from the viewpoint of investors. Second, is to identify the differences in the accounting quality between the shariah compliant and non-shariah compliant companies in pre-and post-implementations of IFRS. Using 2169 firm-year observations from firms listed on the Bursa Kuala Lumpur Stock Exchange over the period of 2008 to 2016, the result shows that the implementation of MFRS have reduced the firms' earnings management. However, this study provides new arguments that Shariah-complaints firms in Malaysia do not necessary have greater incentives to report highquality reporting based on the investor perspectives. Our evidence thus help to explains the different impact on IFRS adoption on accounting quality in Malaysia and shariah complaint compnaies.
\end{abstract}

(C) 2019 The authors, under a Creative Commons Attribution-Non

Commercial 4.0

Corresponding author's email address: ckooi@utar.edu.my

Recommended citation: Keong, O. C., Pengb, L. S. and Lengc, L. W. (2019).The impact of International Financial Reporting Standards (IFRS) on accounting quality in Malaysia. Journal of Accounting and Finance in Emerging Economies, 5 (1), 93-104

DOI: $10.26710 /$ jafee.v5i1.726

\section{Introduction}

Malaysian Financial Reporting Standards (MFRS) is word to word to International Financial Reporting Standards (IFRS) came to effect on 1 January 2012 and are in line with Malaysian Accounting Standards Board (MASB)'s mission to develop and promote high quality accounting and financial reporting standards. The improved accounting quality will benefit users, preparers, auditors and the public in Malaysia. Therefore, this study aims to examine and compare the accounting quality in pre-and post-implementations of IFRS from the viewpoint of investors. Further, this study will identify the differences in the accounting quality between the shariah compliant and non-shariah compliant companies in pre-and post-implementations of IFRS.

The existing studies on accounting standards and accounting quality in particular earnings management were focused on developed countries, for example, United States of America (USA), Australia, United Kingdom (UK) and European studies but few in emerging countries. Thus, this current research will attempt to fill the gap and to 
offer an insight to the effects of improvements in accounting standards on earnings management activities among the public listed firms in Malaysia. To the best of our knowledge in the local scenario in Malaysia, there were only few studies which addressed the impact of IFRS-based accounting standards on earnings management and the results were inconclusive.

This study focuses on the information extracted from the consolidated financial statements of public listed companies listed at Bursa Malaysia before and after the adoption of IFRS. The data consists of annual observations, and covered the period between 2008 and 2016. The sample period selected provides a focus on recent adoption of MFRSs and also ensure sufficient time-frame for pre and post-adoption of IFRS studies. The findings will respond to whether the accounting quality has improved, deteriorated or status quo. Thus, these findings could provide valuable inputs to investors and standard setters in Malaysia.

\section{Literature Review and Hypotheses Development}

Accounting standards are often subjected to continuous changes, modifications and improvements over time. These changes are intended to boost comparison of financial statements between companies, enhance corporate transparency and elevate financial reporting quality (Baig and Khan, 2016). Improvements in standards include clarifying ambiguities in terminologies, removing the alternative accounting treatments and to take into account issues that had not been addressed (Al-Ghazzawi and Alsobao, 2016). Moreover, improvements in standards should add value to the financial reporting to facilitate efficient resource allocation and decision making (Healy and Whalen, 1999).

Ideally, financial reporting could help to distinguish best-performing companies from the poor performing ones in the economy (Healy \& Whalen, 1999) and thus, increase investors' confidence in the financial reporting system (Yurt \& Ergun (2015). However, companies around the world manage reported earnings (Yu, 2014) and manipulate accounting data for a variety of reasons and this manipulation is often known as earnings management. Some companies use earnings management as management of the firms have an incentive to do so (Halaoua, Hamdi and Mejri, 2017), to maintain steady growth in earnings and to avoid reporting in red (Burgstahler and Dichev, 1997), to meet internal management goals to satisfy financial targets ahead of financial closing (Baig and Khan, 2016) and to influence internal decision-making process (Mcnichols and Stubben, 2008). Prior studies (Barth et al., 2008; Iatridis and Dimitras, 2013) regarded earnings management as a determinant of accounting quality. Accounting quality represents "the extent to which the financial statement information reflects the underlying economic situation" (Chen et al, 2010). Thus, improvements in accounting standards were anticipated to reduce earnings management impulse (Al-Ghazzawi and Alsobao, 2016) and therefore enhance accounting quality and consequently improve value relevance of earnings in firms.

Various terminologies were used to describe earnings management, which includes "accounting manipulation", "accounting Hocus-Pocus", "Rumpelstilzchen-accounting or "Bilanzpolitik" and "Gewinnsteuerung" in German literature (Dilger and Graschitz, 2015). However, there seemed to be no agreed definition on earnings management (Al-Ghazzawi and Alsobao, 2016). In the study by Schipper (1989), earnings management was defined as "a purposeful intervention in the external financial reporting process, with the intent of obtaining some private gain". Alternatively, Healy and Whalen (1999) explained that "earnings management occurs when managers use judgement in financial reporting and in structuring transactions to alter financial reports to either mislead some stakeholders about the underlying economic performance of the company, or to influence contractual outcomes that depend on reported accounting practices". According to Wan Ismail, Kamarudin and Sarman (2014), earnings management behaviour involved the maneuvering of earnings figure reflected in the financial statement by discretionary provisions that were permitted by particular accounting standards. Accordingly, it is noticeable that earnings management was made possible due to allowable exercise of judgements available in preparing financial statements, but was constrained by the existence of accounting standards (Wan Ismail, Kamarudin, Zijil and Dunstan, 2013). On the other hand, Mulyasari, Sugiri and Herdhayinta (2016) argued that earnings management has information contents that would degrade earnings quality and thus impact future profitability of firms.

\subsection{IFRS Improves Accounting Quality by Reducing Earnings Management}

There are various studies on improvements in accounting standards which were likely to reduce management's opportunistic discretion, i.e. earnings management. In the local scenario in Malaysia, there were only a few attempts to investigate the impact of IFRS on earnings management in companies. 
Wan Ismail, Kamarudin, Zijl and Dunstan (2013) reported that IFRS adoption is clearly linked to the quality of reported earnings among 4,010 companies over period of three years, i.e. the before and after adoption periods, of the updated accounting standards in Malaysia. With the IFRS adoption, firms reported a more superior quality of reported earnings. With lower earnings management activities observed in the post-adoption periods of IFRS, reported earnings resulted in higher value relevance. Fourati and Ghorbel (2017) addressed the impact of IFRSbased accounting standards on earnings management based on a sample of 3,340 firm-year observations across three reporting periods with different levels of IFRS adoption- pre IFRS period (2003-2005), post FRS period (2007-2011) and post MFRS period (2013-2014). The results of the regression to examine the effect of IFRS on earnings management employed the Kothari et al. (2005) model discovered that adoption of IFRS decreased earnings management practices in the partial convergence period. However, after full convergence to IFRS, the effect became restrictive.

The similar findings was highlighted in the study by Sellami and Fakhfakh (2013) where the Dechow et al. (1988) model were exploited to show a decrease in absolute value of discretionary accruals among a sample of 124 French companies during the post-IFRS period. It was also suggested that improvements in accounting standards led to the lessening of earnings management, further timely loss recognition and improved value relevance among these listed firms in the London Stock Exchange during the 2004 and 2005 period (Iatridis, 2010). Barth et al. (2008) studied on companies in 21 countries and discovered declining earnings management levels and less income smoothing due to the firms' early voluntary adoption of IAS/IFRS over the period of 1994-2003, which also suggested that quality of financial reporting increased with these adoptions.

Mandatory first time adoption of IAS/IFRS in France is associated with lesser earnings management level (Zighal, Chtourou and Sellami, 2011). The authors conducted this study based on 353 French-listed companies utilizing the information extracted from annual reports and other secondary sources for a 4 year period from 2003- 2006. It was also highlighted that earnings management were affected by corporate governance factors (independent and efficient of board of directors, audit committee, existence of block shareholders, external auditors and listing on foreign financial markets) - all of which are vital implementation factors of IAS/IFRS in France. In this study, discretionary accruals was employed to measure earnings management practices and had adopted the model by Kothari, Leone and Wesley (2005).

From the perspective of agency theory, implementation of IFRS enforced investor protection among a sample 106 listed companies in Germany, France and Belgium that reduced the motivation to manage earnings. This is due to the transition into IFRS made communication of accounting information more relevant (Kuoki, 2017). Hence, IFRS and investor protection were highlighted to be jointly significant to explain earnings management activities.

Liu and O'Farrell (2011) also discovered that mandatory adoption of IFRS increased accounting quality and reduced earnings management in the companies in China. Bouchareb et al. (2014)'s study in the France context revealed that the level of discretionary accruals decreased significantly after the adoption of IFRS. Chen et al. (2010) explored the relationship between IFRS adoption and earnings management levels among companies in the European Union. Results showed that the levels of earnings management reduced after IFRS adoption as the magnitude of absolute discretionary accruals declined.

\subsection{IFRS Does Not Improve Accounting Quality as Earnings Management Activities Increases}

On the other hand, some past studies highlighted contradicting findings in that adoption of IFRS does not reduce the earnings management intentions.

Improvements in International Accounting Standards (IASs) which were mandatorily adopted from 1 January 2005 in Jordanian Industrial Corporations did not result in lower earnings management practices (Al-Ghazzawi and Alsobao, 2016). The evidence from China in the study conducted by Zhang, Uchida and Bu (2013) showed that earnings management increased significantly after the adoption of IFRS-convergent new accounting standards. Ahmed, Neel and Wang (2013) discerned that firms showed substantial increases in income smoothing and vigorous reporting of accruals and a substantial decline in the timeliness of loss recognition. Ames (2013)'s findings on the South African firms concurred with the findings of Al-Ghazzawi and Alsobao (2016) and Ahmed et al. (2013) in that earnings quality did not significantly improve in post-adoption of IFRS standards. Jeanjean and 
Stolowy (2008)'s study on the Australian, France and United Kingdom firms showed that occurrence of earnings management did not reduce in the post-IFRS period but surprisingly increased in France.

In the European Union context, Gray et al. (2015) examined public listed companies from 14 European Union countries and the results indicated that earnings management activities continued to be prevalent even after the implementation of IFRS among companies. Doukakis (2014) scrutinized the effect of compulsory implementation of IFRS on accrual-based and real earnings management. This study was based on the inspection of 15,206 samples from 22 countries in Europe between years 2000-2010. Findings suggested that there is no noteworthy effect of implementation of IFRS on accrual-based or real earnings management levels. Conversely, firm-level reporting incentives played a primary role in shaping accounting quality.

Kabir et al. (2010) highlighted that IFRS adoption among 118 companies in New Zealand increased the absolute value of discretionary accruals. The study by Watrin and Ullmann (2012) on German companies from 1994-2005 revealed that voluntary implementation of IFRS does not reduced the earnings management level.

As portrayed by past studies discussed above, the studies indicated that there were mixed or not unanimous findings as to whether the transition to IFRSs/IASs and/or improvements in accounting standards deters or contributes to greater earnings management activities. An explanation to these mixed evidences as suggested by Capkun, Collins and Jeanjean (2016) was "self-selection" on the adoption of IFRS. Moreover, the existing studies on accounting standards and earnings management focused on USA, UK and European studies. Thus, this current research will attempt to fill the gap and to offer an insight to the effects of improvements in accounting standards on earnings management activities among the public listed firms in Malaysia. Although the results are mixed we nevertheless, posit the following hypothesis:

Hypothesis 1: The implementation on IFRS will improve accounting quality in term of reducing earning management.

\subsection{Shariah Compliant Companies and Earnings Management}

Wan Ismail, Kamarudin and Sarman (2014) investigated the reported earnings quality of 508 Shariah-compliant companies listed on Bursa Malaysia for a period of six years from 2003-2008. In this study, earnings quality were measured using the accrual quality model by Dechow and Dichev (2002) which relate total current accruals lagged, current and future cash flows from operations. The authors argued that companies which were Shariah-compliant were subject to stricter regulatory assessments by regulators/institutional investors as there are three-levels of screening by Shariah Advisory Council, established under the Securities Commission. As such, the Shariahcompliant companies possessed better quality accounting information and better quality of accruals. The Shariahcompliant companies were also subject to the Islamic ethical code of conduct which limit the unethical behaviour and therefore enhanced financial reporting value relevance. It highlighted that the availability of enhanced financial reporting quality by Shariah-compliant companies boost foreign investments to Malaysia. This meant that the Shariah-compliant companies possessed higher quality of accruals as opposed to non-Shariah-compliant companies. Based on the above-mentioned discussions lead us to the following hypothesis

Hypothesis 2: Shariah-compliant companies have a higher accounting quality in term of lesser earning management, compare to non-Shariah-compliant companies.

\subsection{Corporate Governance, Audit Quality, Company Size and Leverage And Earnings Management}

In line with agency theory and corporate governance reports (Cadbury, 1992), the existence of independent outside directors increases the effectiveness of companies, minimizes fraud and reduces earnings management (Xie et al., 2003). Board size were highlighted to have a significant influence on board's performance and efficiency and could curb fraud (Beasley, 1996). It was also found that board size had an effect on earnings management (Xie et al., 2003). Duality of board of directors (BOD) in that the chief executive officer is also the chairperson of BOD had been reported to reduce agency costs in large companies (Fama and Jensen, 1983; Beasley, 1996; Xie et al., 2003). In addition, the study by Mohd Saleh, Mohd Iskandar and Rahmat (2005) also revealed that the multiple directorship is inversely related to earnings management activities and thus, duality of BOD is effective to reduce the earnings management levels. However, according to the authors, independence of BOD as indicated by percentage of outside BOD did not have a significant impact in mitigating earnings management practices in companies. 
Audit quality by bigger and more reputable audit firms were presumed to provide higher audit quality and that higher audit quality reduces earnings management levels (Ben Othman and Zeghal, 2006; Van Tendeloo and Vanstraelen, 2005). By having more reputable auditors, e.g. BIG-4 firms to conduct the audit work, the better is the audit quality and hence, resulted in higher reported earnings quality (Krishnan, 2003). Company size as measured by total assets of the firm was emphasized in the study by Zeghal, Chtourou and Sellami (2011) as having an impact on earnings management practices. Larger companies have more incentives to reduce earnings management and larger companies are often associated with more reliable financial statements (Bedard et al., 2004) and better disclosure quality (Super and Shil, 2017), thus limiting earnings management practices. Firm size was also found to be positively related to accrual quality (Deechow and Dichev, 2002). In the study by Zeghal, Chtourou and Sellami (2011), debt levels of companies as measured by the ratio of total debt over total asset have a vague relationship to earnings management. Firms with larger debts may have a higher tendency to resort to earnings management in an attempt not to violate debt covenants (Ben Othman and Zeghal, 2006). It was also suggested by Super and Shil (2017) that firms with higher leverage tend to have lower disclosure quality, suggested a tendency to manage earnings. Contrast to the above, study by Lazzem and Jilani (2018) on French firms and Christensen, Lee, Walker and Zeng (2015) on German firms suggested that firm leverage has a positive impact on earnings management as increased leverage provided incentives for managers to carry out earnings management activities.

\section{Data and Methodology}

\subsection{Sample}

This study begins with top 300 firms listed on the Malaysian stock exchange between 2008 and 2016. This period is selected due to the implementation of MFRS in 2012 financial statements. We exclude data from 2012, as this is the year of implementation to MFRS. We then remove banks and financial institutions, and REIT observation to enhance comparability. We also remove firms with missing financial statement data, corporate governance and auditor information. Thus, a total of 241 listed firms are used in the analyses. The annual financial data is obtained from the Bloomberg database. The corporate governance and auditor information is manually collect from the annual reports of listed firms. In this study, the sample is further divided into two subsamples (pre-MFRS period from 2008 to 2011 and post-MFRS period from 2013 to 2016).

Table 1 presents the descriptive statistics relating to variables used in our tests. Firms in post implementation MFRS generally have higher total assets and total debts in our sample. The average firm in our sample has total assets of RM3, 250 million and RM4, 865 million in pre- and post-MFRS periods, respectively. The mean of total debt in pre-MFRS is RM943 million, which is significantly different compare to port-MFRS is RM1, 409 million. The corporate governance variable of firm board size on average is 8 board member on the board, and is not significant different in the pre- and post-MFRS implementation. On average, 70 percent of our sample are audited by Big4 auditor. With respect to the number of independent directors and duality of CEO and chairperson indicating that their variations are fairly small in the post-MFRS periods. Table 1 shows that approximate 73 to 80 per cent are Shariah-compliant firms in our sample.

\section{Table 1: Descriptive statistics}

\begin{tabular}{|c|c|c|c|c|c|}
\hline & \multicolumn{2}{|c|}{ Pre-MFRS (2008-2011) } & \multicolumn{2}{|c|}{ Post-MFRS (2013-2016) } & \multirow{2}{*}{$\begin{array}{l}\text { Test of Difference } \\
\text { between the two } \\
\text { groups t-Statistics }\end{array}$} \\
\hline & Mean & S.D & Mean & S.D & \\
\hline $\begin{array}{l}\text { Total assets } \\
\text { million) }\end{array}$ & $3,249.812$ & $8,253.775$ & $4,864.664$ & $12,375.420$ & $-3.367 * * *$ \\
\hline Total debt (RM million) & 942.968 & $3,007.150$ & $1,408.621$ & $4,019.804$ & $-2.876 * * *$ \\
\hline Board size & 8.013 & 1.850 & 7.997 & 1.947 & 0.181 \\
\hline $\begin{array}{l}\text { Number of independent } \\
\text { directors } \\
\text { CEO/Chairperson }\end{array}$ & 3.493 & 1.090 & 3.618 & 1.123 & $-2.471 * *$ \\
\hline Duality & 0.231 & 0.410 & 0.174 & 0.380 & $2.158 * *$ \\
\hline Big4 & 0.691 & 0.462 & 0.695 & 0.461 & -0.205 \\
\hline Shariah-compliant firms & 0.801 & 0.399 & 0.733 & 0.442 & 1.540 \\
\hline
\end{tabular}


Table 2 presents the correlation matrix between variables in our regression. The correlation matrix in Panel A and B show that the Pearson correlations between discretionary accrual ("DA") and other variables use in the model are relatively small, except for the total assets and leverage variables. All the correlation coefficients are less than (0.70), limit from multicollinearity.

\section{Table 2: Correlation matrix}

\begin{tabular}{|c|c|c|c|c|c|c|c|c|}
\hline & BSize & Indep. & Dual & Big4 & Size & Leverage & Shariah & $\mathrm{DA}$ \\
\hline \multicolumn{9}{|c|}{ Panel A: correlation matrix among variables (Pre-MFRS period: 2008-2011) } \\
\hline BSize & 1.000 & & & & & & & \\
\hline Indep. & $0.517 * * *$ & 1.000 & & & & & & \\
\hline Duality & $-0.084 * *$ & -0.060 & 1.000 & & & & & \\
\hline Big4 & $0.106^{* * *}$ & $0.079 * *$ & -0.055 & 1.000 & & & & \\
\hline Size & 0.204 & 0.222 & -0.058 & $0.108 *$ & 1.000 & & & \\
\hline Leverage & 0.198 & $0.161 *$ & $0.075^{*}$ & $-0.067 * *$ & $0.611 * * *$ & 1.000 & & \\
\hline Shariah & -0.025 & $0.096 * *$ & 0.042 & -0.027 & -0.062 & -0.003 & 1.000 & \\
\hline DA & -0.033 & -0.043 & $-0.064 *$ & -0.013 & 0.124 & $0.144 * * *$ & $\overline{0} .085 * *$ & 1.000 \\
\hline \multicolumn{9}{|c|}{ Panel B: correlation matrix among variables (Post-MFRS period: 2012-2016) } \\
\hline BSize & 1.000 & & & & & & & \\
\hline Indep. & $0.562 * * *$ & 1.000 & & & & & & \\
\hline Dual & -0.011 & -0.046 & 1.000 & & & & & \\
\hline Big4 & $0.068 * *$ & $0.054^{*}$ & -0.010 & 1 & & & & \\
\hline Size & $0.231 * *$ & $0.302 * * *$ & -0.020 & $0.102 *$ & 1 & & & \\
\hline Leverage & $0.259 * *$ & 0.256 & $0.058^{*}$ & $-0.069 * *$ & $0.626^{* * *}$ & 1 & & \\
\hline Shariah & 0.009 & 0.012 & -0.007 & -0.043 & -0.039 & $-0.063^{*}$ & 1 & \\
\hline DA & -0.037 & $-0.121 *$ & $-0.125^{*}$ & -0.020 & 0.091 & $0.107 * * *$ & $0.067 * *$ & 1 \\
\hline
\end{tabular}

\subsection{Methodology}

\subsubsection{Estimation of Discretionary Accruals}

This study uses the discretionary accruals as the proxy of earning management. Studies such as Jones (1991), Dechow et al. (1995) Leuz et al. (2003) and Kothari et al. (2005) have proposed various models to measure discretionary accruals. We adopt Kothari et al. (2005) model to compute discretionary accruals because it has been widely used in the previous studies. It is shown in equation (1) below:

$$
\frac{\mathrm{TAAC}_{\mathrm{it}}}{\mathrm{TA} A_{\mathrm{it}-1}}=\beta_{0}+\beta_{1}\left(\frac{1}{\mathrm{TA} A_{\mathrm{it}-1}}\right)+\beta_{2}\left(\frac{\Delta \mathrm{REV}_{\mathrm{it}}-\Delta \mathrm{REC}_{\mathrm{it}}}{\mathrm{TA} A_{\mathrm{it}-1}}\right)+\beta_{3}\left(\frac{\mathrm{PPE}_{\mathrm{it}}}{\mathrm{TA}_{\mathrm{it}-1}}\right)+\beta_{4}\left(\mathrm{ROA}_{\mathrm{it}}\right)+\varepsilon_{\mathrm{it}}
$$

where TACCit is the total accruals, calculated as firm i's net income minus cash flow from operations in year t; TAit-1 is total assets for firm $\mathrm{i}$ in year $\mathrm{t}-1 ; \Delta \mathrm{REV}$ it is the change in revenues for firm $\mathrm{i}$ between year $\mathrm{t}$ and $\mathrm{t}-1$; $\triangle$ RECit is the change in account receivable for firm $i$ between year $t$ and $t-1$; PPEit is the gross property, plant and equipment for firm $\mathrm{i}$ in year $\mathrm{t}$, ROAit is the return on assets for firm $\mathrm{i}$ in year $\mathrm{t}$ and cit is the error term.

Discretionary accruals proxy can only be obtained by calculating the difference between the total accruals and the estimated non-discretionary accruals. The discretionary accruals (DA) are defined as: 


$$
\left|\mathrm{DA}_{\mathrm{it}}\right|=\mathrm{TACC}_{\mathrm{it}}-\left[\bar{\beta}_{0}+\bar{\beta}_{1}\left(\frac{1}{\mathrm{TA} A_{\mathrm{it}-1}}\right)+\bar{\beta}_{2}\left(\frac{\Delta \mathrm{REV}_{\mathrm{it}}-\Delta \mathrm{REC}_{\mathrm{it}}}{\mathrm{TA} A_{\mathrm{it}-1}}\right)+\bar{\beta}_{3}\left(\frac{\mathrm{PPE}_{\mathrm{it}}}{\mathrm{TA} \mathrm{A}_{\mathrm{it}-1}}\right)+\bar{\beta}_{4}\left(\mathrm{ROA}_{\mathrm{it}}\right)\right]
$$

where $\bar{\beta}_{0}, \bar{\beta}_{1}, \bar{\beta}_{2}, \bar{\beta}_{3}, \bar{\beta}_{4}$ is the estimated coefficients of $\beta_{0}, \beta_{1}, \beta_{2}, \beta_{3}, \beta_{4}$.

\subsubsection{Regression Model}

Studies such as Dechow et al. (1996), Xie et al. (2003) and Ghose et al. (2010) examine the structure and composition of a board and how they influence financial reporting. In our study, we specifically focus on the board size, board independence and separation of CEO and board chairperson. To analyse the relation between corporate governance and earnings management, after controlling for the impact of firm specific variables. The following model is employed:

$$
\begin{gathered}
\left|\mathrm{DA}_{\mathrm{it}}\right|=\alpha+\beta_{1} \text { LnBSize }_{i t}+\beta_{2} \text { Independence }_{i t}+\beta_{3} \text { Duality }_{i t}+\beta_{4} \text { Big }_{i t}+\beta_{5} \text { LnSize }_{i t}+\beta_{6} \text { Leverage }_{i t} \\
+\beta_{7} \text { Shariah }_{i t}+\text { Fixed effects }+\varepsilon_{i t}
\end{gathered}
$$

Where

IDAitl is the discretionary accruals calculated from equation (2). Board size (LnBSizeit) is measured in the natural logarithm of the number of directors on board. Board independence ((Independenceit) is the percentage of independent outside directors serving on the board. Dualityit is dummy variable equal to one when a firm has a separate CEO and board chairperson and 0 otherwise. Xie et al. (2003) suggest that board size is associated to the extent of earnings management. If larger board is associated with more (less) efficient in monitoring earnings management, $\beta 1$ is likely to be negative (positive). According to Fama and Jensen (1983) due to outside directors are very concerned their reputation in the managerial labour market, they are to be more efficient in monitoring management compare to insider directors. Thus, a board with greater percentage of outside directors are believe to be more independent, leading to lower earnings management, $\beta 2$ is expected to be negative. $\beta 3$ is expected to be positive because when CEO also holding the Chair of the board are more powerful and thus have greater influence over board members.

Based on previous studies this study includes firm specific control variables that could influence top managers' motivation to "manage" earnings (Houqe et al., 2016; and Dauth et al., 2017). We use Big4 auditor as a control variable, the choice of auditor is proxy for the quality of the audit undertaken. Francis and Wang (2008) suggest that the presence of Big4 auditors limit accruals earnings management practices. Therefore, $\beta 4$ is expected to have a negative relationship with discretionary accruals. Big4 is a dummy variable that takes the value of one if the firm financial statements are audited by Big4 audit firm and 0 otherwise. We also include the natural logarithm of total asset (LnSizeit) as a control variable to control for firm size on earnings management. Prior studies provide inconsistent evidence with regard of firm size effects on earning management. Scott (1991) and Callao and Jarne (2010) find that large firms more incline to "manage" earnings because they of are more visible than small firms, and the complexity of operations makes detecting overstatement more difficult (Lobo and Zhou, 2006). Therefore, $\beta 5$ is expected to have positive relation with discretionary accruals. Studies such as DeFond and Jiambalvo (1994) and Francis and Wang (2008) highly leverage firms are more likely have earnings management practices to avoid debt covenant violation. We include leverage to pick up debt contracting incentives of earnings management. Leverageit is the debt ratio calculated as total debt divided total assets of firm i's in year t, $\beta 6$ is likely to be expected to be positive. Another control variable is the Shariah-complaint firm, Shariah is dummy variable equal to one when a firm is listed as Shariah-compliant firm and 0 otherwise. We expect $\beta 7$ is negative relation with discretionary accruals as Shariah-compliant firms are subject to greater scrutiny from regulators. In addition, we control for the effect of time periods and industry by including year and industry dummy variables. Fixed effects are industry dummies and year dummies, a vector of dummy variables indicating year and industry sector, respectively.

\section{Results}

\subsection{Earnings Management In Pre- and Post-MFRS Periods}

To analyse whether the implementation of MFRS would reduce the earning management level, we split our sample into pre-MFRS (2008-2011) and post-MFRS (2013-2016) periods. Table 3 presents the results of comparing the two periods. The high amount of discretionary accruals means company management may be more likely to overstate earnings. The means of all sub-groups for the pre-MFRS period is significantly higher than post-MFRS 
period. Furthermore, the results in Table 3 shows that the gap of mean between the group of $\mathrm{DA} \geq 0$ and $\mathrm{DA}<0$ is larger in pre-MFRS compare to post-MFRS period. These results suggest that the implementation of MFRS might reduce the firms' earnings management. One possible explanations is that implementation of MFRS has limited the choice of accounting methods through reduction of creating accounting and increase the accounting quality.

Table 3:

\begin{tabular}{|c|c|c|c|c|c|}
\hline & \multicolumn{2}{|c|}{$\begin{array}{l}\text { Pre-MFRS } \\
\text { 2011) }\end{array}$} & \multicolumn{2}{|c|}{ Post-MFRS (2013-2016) } & \multirow{2}{*}{$\begin{array}{l}\text { Test of } \\
\text { Difference } \\
\text { between the two } \\
\text { groups t-Statistics }\end{array}$} \\
\hline & Mean & S.D & Mean & S.D & \\
\hline DA & -0.0157 & 0.0228 & -0.0118 & 0.0347 & $-2.632 * * *$ \\
\hline $\mathrm{DA}<0$ & -0.0241 & 0.0201 & -0.0204 & 0.0310 & $-3.209 * * *$ \\
\hline $\mathrm{DA} \geq 0$ & 0.0181 & 0.0250 & 0.0055 & 0.0152 & $3.544 * * *$ \\
\hline
\end{tabular}

\subsection{Regression Results}

This study use random effects GLS method for the regression analyses. Breusch-Pagan LM test is applied to verify the presence of random effect. The test result in Table 4 indicates that the null hypothesis of the absence of random effect is rejected ( $\mathrm{p}$-value is $0.0000<0.05$ ). Therefore, the random effect is appropriate in our study.

Table 4:

\begin{tabular}{|c|c|c|c|c|c|}
\hline Variables & & & & & \\
\hline Intercept & & -0.0010 & -0.0986 & -0.0248 & -1.4492 \\
\hline LnBSize & - & $-0.0070^{*}$ & -1.8683 & 0.0066 & 0.8071 \\
\hline Independent directors & - & 0.0024 & 0.8706 & -0.0082 & -1.5492 \\
\hline Duality & + & -0.0003 & -0.1702 & -0.0106 & -1.5643 \\
\hline Big4 & - & -0.0004 & -0.1401 & 0.0027 & 0.6077 \\
\hline LnAssets & + & $0.0029 * * *$ & 2.7524 & $0.0044 * * *$ & 2.6087 \\
\hline Leverage & + & $0.0262 * * *$ & 6.1857 & $0.0683 * * *$ & 5.4966 \\
\hline Shariah & - & $-0.0036^{*}$ & -1.8550 & -0.0003 & 0.1097 \\
\hline Observation & & 964 & & 964 & \\
\hline R-squared & & 0.0743 & & 0.1066 & \\
\hline F-statistic & & $\begin{array}{l}4.9432 \\
(0.0000)\end{array}$ & & $\begin{array}{l}7.5446 \\
(0.000)\end{array}$ & \\
\hline Breusch-Pagan LM & & $\begin{array}{l}62.1175 \\
(0.0000)\end{array}$ & & $\begin{array}{l}64.3877 \\
(0.0000)\end{array}$ & \\
\hline Wald Chi-square & & $\begin{array}{l}46.3950 \\
(0.0000)\end{array}$ & & $\begin{array}{l}33.5268 \\
(0.0000)\end{array}$ & \\
\hline Industry fixed effects & & Included & & Included & \\
\hline Year fixed effects & & Included & & Included & \\
\hline
\end{tabular}

Pre-MFRS period (2008-2011). To evaluate the impact of corporate governance on earning management, we included board size, independent directors and CEO-chairperson duality. The regression results in Table 4 show that in the pre-MFRS period, the coefficient of board size is negative and statistically significant. This suggests that firm with greater number of members on board is associated with lower discretionary accruals. As for the other two CG variables, the independent directors and CEO-chairperson duality, the coefficients are not significant associated with discretionary accruals.

With respect to control variables, the coefficient of Big4 is not significant associated with discretionary accruals. The firm size has a significant positive impact on discretionary accruals. In term of leverage, the coefficient 100 
indicates positive sign and statistically significant, this suggests that the company having more debt is more likely to manage its earning. The coefficient of the Shariah dummy is negative sign and statistically significant associated with discretionary accruals. This means Shariah-complaint firms have lower incentive to manage earnings.

Post-MFRS period (2013-2016). Overall, the results in the post-MFRS period are qualitative similar with preMFRS. However, the board size and Shariah dummy variables are not significant associated with discretionary accruals. We might conclude that the CG variables have less influence on earnings management. The results also suggest that firm size and firm leverage are important factors on earnings management in pre- and post MFRS periods.

The pre- and post-MFRS samples are further separate into two sub-groups: (i) group positive DA (DA $\geq 0$ ) and; (ii) group negative DA $(\mathrm{DA}<0)$. The regression results are presented in Table 5. Regarding the pre-MFRS period, the CEO-chairperson duality had a positive and significant influence on positive discretionary accruals. The coefficient of firm size and leverage indicate that the greater of firm size and leverage have significant pressure in the group of positive discretionary accruals. Whereas in the group of negative discretionary accruals, the CEO-chairperson duality and firm size variables are not significant influence the discretionary accruals. Comparing the results in post-MFRS period analysis indicates that the corporate governance and control variables are less influence on the discretionary accrual.

\section{Conclusion}

This study examines the relationship between implementation of IFRS and accounting quality in term of earnings management, particularly with respect to discretionary accrual. This study suggest that the implementation of MFRS have reduced the firms' earnings management in the post IFRS period. However, this study provides new arguments that Shariah-complaints firms in Malaysia do not necessary have greater incentives to report high-quality reporting based on the investor perspectives although shariah- compliant firms are subject to greater scrutiny from regulators. The results are robust even after separate our samples into positive DA \& negative DA. Overall, the result provide support that implementation of IFRS reduce earnings management but do not necessary apply to Shariah compliant firms

Table 5: Regressions results for positive and negative discretionary accruals

\begin{tabular}{|c|c|c|c|c|c|c|c|c|c|}
\hline & \multirow{3}{*}{$\begin{array}{l}\text { Expected } \\
\text { sign }\end{array}$} & \multicolumn{4}{|c|}{ Pre-IFRS (2008-2011) } & \multicolumn{4}{|c|}{ Post-MFRS (2013-2016) } \\
\hline & & \multicolumn{2}{|c|}{ Positive DA (DA $\geq 0)$} & \multicolumn{2}{|c|}{ Negative DA $(\mathrm{DA}<0)$} & \multicolumn{2}{|c|}{ Positive DA (DA $\geq 0)$} & \multicolumn{2}{|c|}{ Negative DA $(\mathrm{DA}<0)$} \\
\hline Intercept & & 0.0090 & 2.0097 & -0.0048 & -0.4233 & 0.0388 & 1.5230 & -0.0205 & -1.5323 \\
\hline LnBSize. & - & -0.0049 & -1.5838 & $-0.0071^{*}$ & -1.7352 & 0.0067 & 1.1255 & 0.0023 & 0.4618 \\
\hline Independent directors & - & -0.0021 & -0.9415 & 0.0003 & 0.1054 & -0.0031 & -0.3463 & -0.0140 & -1.5710 \\
\hline Duality & + & $0.0047^{* * *}$ & 4.6123 & -0.0028 & -1.3214 & -0.0023 & -0.8172 & 0.0054 & 1.1195 \\
\hline Big4 & - & -0.0012 & -0.9398 & 0.0004 & 0.1367 & $-0.0187^{* *}$ & -2.3739 & $-0.0038^{*}$ & -1.7618 \\
\hline LnAssets & + & $0.0026 * * *$ & 6.2717 & 0.0017 & 1.4232 & 0.0006 & 0.0560 & -0.0063 & -1.2129 \\
\hline Leverage & + & $0.0301 * * *$ & 6.6028 & $0.0276^{* * *}$ & 4.6393 & $0.0366^{* * *}$ & 2.6074 & $0.0627^{* *}$ & 2.2454 \\
\hline Shariah & - & -0.0055 & -1.2302 & -0.0032 & -1.4725 & -0.0006 & -0.1394 & -0.0010 & -0.3258 \\
\hline Observation & & 71 & & 170 & & 70 & & 171 & \\
\hline R-squared & & 0.1157 & & 0.0816 & & 0.1768 & & 0.0978 & \\
\hline F-statistic & & $\begin{array}{l}2.6046 \\
(0.0054)\end{array}$ & & $\begin{array}{c}3.4565 \\
(0.0000)\end{array}$ & & $\begin{array}{l}2.0585 \\
(0.0213)\end{array}$ & & $\begin{array}{c}3.5902 \\
(0.0000)\end{array}$ & \\
\hline Breusch-Pagan LM & & $\begin{array}{l}22.4309 \\
(0.0000)\end{array}$ & & $\begin{array}{l}40.9549 \\
(0.0000)\end{array}$ & & $\begin{array}{l}20.6080 \\
(0.0000)\end{array}$ & & $\begin{array}{l}49.9253 \\
(0.0000)\end{array}$ & \\
\hline Wald Chi-square & & $\begin{array}{l}12.0747 \\
(0.0071)\end{array}$ & & $\begin{array}{l}24.1375 \\
(0.0002)\end{array}$ & & $\begin{array}{l}12.6877 \\
(0.0265)\end{array}$ & & $\begin{array}{l}17.3006 \\
(0.0082)\end{array}$ & \\
\hline Industry fixed effects & & Included & & Included & & Included & & Included & \\
\hline Year fixed effects & & Included & & Included & & Included & & Included & \\
\hline
\end{tabular}

\section{Acknowledgement}

This research paper is under the funding of the Universiti Tunku Abdul Rahman (UTAR)'s Internal Research Fund (UTARRF) and the authors greatly express deep appreciation to UTAR which has provided funding for this research. 


\section{References}

Ahmed Kouki, (2018) "Mandatory IFRS adoption, investor protection and earnings management: A data analysis of Germany, France and Belgium listed companies", International Journal of Accounting \& Information Management, Vol. 26 Issue: 1, pp.187-204, https://doi.org/10.1108/IJAIM-07-2017-0091

Ahmed, A.S., Neel, M. and Wang, D. (2013). Does mandatory adoption of IFRS improve accounting quality? Preliminary evidence. Contemporary Accounting Research, 30(4), 1344-1372.

Al-Ghazzawi, A.M. and Alsobao, S.S. (2016). Impact of improvements to the international Accounting Standards on earnings management on the Jordanian Industrial Corporations. Journal of Accounting and Finance, $16(2)$.

Ames, D. (2013). IFRS adoption and accounting quality: The case of South Africa. Journal of Applied Economics and Business Research, 3(3), 154-165.

Baig, M and Khan, S. A. (2016). Impact of IFRS on earnings management: Comparison of pre-post IFRS era in Pakistan. Procedia- Social and Behavioral Sciences, 230, 343-350.

Ball, R., Kothari, S. and Robin, A. (2000). The effect of international institution factors on properties of accounting earnings. Journal of Accounting and Economics. 29(1), 1-51.

Barth, M.E., Landsman, W.R., \& Lang, M. H. (2008). International accounting standards and accounting quality. Journal of Accounting Research, 46(3), 467-498.

Beaseley, M.S. (1966). An empirical analysis of the relation between the board of director composition and financial statement fraud. Accounting Review, 71, 443-465.

Bedard, J. , Chtourou, S.M. and Courteau, L. (2004). The effect of audit committee expertise, independence and activity on aggressive earnings management. Auditing: A Journal of Practice and Theory, 23(2), 13-35.

Ben Othman, H. and Zeghal, D. (2006). A study of earnings management motives in the Anglo-American and Euro Continental accounting models: The Canadian and French cases. The International Journal of Accounting, $141,406-435$

Bouchareb, M. (2014). Does the Adoption of IAS/IFRS with a Strong Governance Mechanism Can Deter Earnings Management?. International Journal of Academic Research in Economics and Management Sciences, 3(1), 264.

Bouchareb, M., Ajina, A. and Souid, S. (2014). Dies the adoption of IAS/IFRS with a strong governance mechanism can deter earnings management? International Journal of Academic Research in Economics and Management Services, 3(1), 264-282.

Burgstahler, D. and Dichev, I. (1997). Earnings management to avoid earnings decreases and losses. Journal of Accounting and Economist. 24(1), 99-126.

Cadbury, A. (1992). Report of the committee on the financial aspects of corporate governance.

Capkun, V., Collins, D. and Jeanjean, T. (2016). The effect of IAS/IFRS adoption on earnings management (smoothing): A closer look at competing explanations. J. Account. Public Policy. 35, 352-394

Christensen, H.B., Lee, E., Walker, M. \& Zeng (2015). Incentives or standards: What determines accounting quality changes around IFRS adoption? Eur. Acc. Rev. 24(1), 31-61

Chen, H., Tang, Q., Jiang, Y. and Lin, Z. (2010). The role of IFRS in Accounting Quality: Evidence from European Union. Journal of International Financial Management and Accounting, 21(3). 1-57.

Chen, J. J., \& Zhang, H. (2010). The impact of regulatory enforcement and audit upon IFRS compliance-Evidence from China. European Accounting Review, 19(4), 665-692.

Dechow, P. M., \& Dichev, I. D. (2002). The quality of accruals and earnings: The role of accrual estimation errors. The accounting review, 77(s-1), 35-59.

Deechow, P.M., Sloan, R. G. and Sweeney, A.P. (1995). Detecting earnings management. The Accounting Review, 70(2), 193-225.

Dilger, T. and Graschitz, S. (2015). Influencing factors on earnings management: Empirical evidence from listed German and Austrian companies. International Journal of Business and Economic Sciences Applied Research, 8(2), 69-86.

Doukakis, L. C. (2014). The effect of mandatory IFRS adoption on real and accrual-based earnings management activities. Journal of Accounting and Public Policy, 33(6), 551-572.

Fama, E.F. and Jensen, M.C. (1983). Separation of ownership and control. Journal of Law and Economics,

26, 301-325.

Fourati, Y.M. and Ghorbel, R.C. (2017). The impact of IFRS-based accounting standards on earnings management: evidence from Malaysia. International Journal of Accounting and Economics Studies, 5(1), 1-6.

Frankel, R. and Li, X. (2004) Characteristics of a firm's information environment and the information asymmetry between insiders and outsiders, Journal of Accounting and Economics, 37(2), 229-259. 
Gray, S. J., Kang, T., Lin, Z., \& Tang, Q. (2015). Earnings management in Europe post IFRS: do cultural influences persist?. Management International Review, 55(6), 827-856.

Halaoua, S., Hamdi, B. \& Mejri, T. (2017). Earnings management to exceed thresholds in continental and AngloSaxon accounting models: The British and French cases. Research in International Business and Finance, 513-529.

Healy, P. and Whalen, J.M. (1999). A review of the earnings management literature and its implications for standard setting. Accounting Horizons, 13(4), 365-383.

Iatridis, G. (2010). International Financial Reporting Standards and the quality of financial statement information. International Review of Financial Analysis, 19, 193-204.

Ismail, W.A.W., Kamarudin, K.A., Zijl, T. and Dunstan, K. (2013). Quyality earnings and the adoption of IFRSbased accounting standards: Evidence from an emerging market. Asian Review of Accounting, 21(1), 5373.

Jeanjean, T. and Stolowy, H. (2008). Do accounting standards matter? An exploratory analysis of earnings management before and after IFRS adoption. Journal of Accounting and Public Policy, 27(6), 480-494.

Kabir, M. H., Laswad, F., \& Islam, M. A. (2010). Impact of IFRS in New Zealand on accounts and earnings quality. Australian Accounting Review, 20(4), 343-357.

Kothari, S. P., Leone, A. J., \& Wasley, C. E. (2005). Performance matched discretionary accrual measures. Journal of accounting and economics, 39(1), 163-197.

Krishnan, G.V. (2003). Does Big-6 auditor industry expertise constrain EM? Accounting Horizons, 17, 1-16.

Kuoki, A. (2017). Mandatory IFRS adoption, investor protection and earnings management - A data analysis of Germany, France and Belgium listed companies. International Journal of Accounting and Information Management, 26(1), 187-204.

Lang, M., Raedy, J. and Yetman, M. (2003). How representative are firms that are cross listed in the United States? An analysis of accounting quality. Journal of Accounting Research, 41(2), 363-86.

Lazzem, S. \& Jilani, F. (2018). The impact of leverage on accrual-based earnings management: The case of listed French firms. Research in International Business and Finance. 44, 350-358

Leuz, C., Nanda, D. and Wysocki, P. (2003). Earnings management and investor protection: An international comparison. Journal of Financial Economics. 69(3), 505-528.

Leventis, S., Dimitropoulos, P. and Owusu-Ansah, S. (2013). Corporate governance and accounting conservatism: Evidence from the Banking Industry. Corporate Governance: An International Review, 21(3), 264-286.

Liu, C and O'Farrell, G. (2011). The impact of IFRS on earnings management: Evidence from the People's Republic of China. International Journal of Services and Standards, 17(3/4), 264-277.

Mcnichols, M.F. and Stubben, S. R. (2008). Does earnings management affect firm's investment decisions? The Accounting Review. 83(6), 1571-1603.

Mohd Salleh, N. and Mohd Iskandar, T. and Rahmat, M.M. (2005). Earnings management and board characteristics: Evidence from Malaysia. Jurnal Pengurusan, 24, 77-103.

Mulyasari, W., Sugiri, S. and Herdhayinta, H. (2016). Information content on earning: Implications on growth and value companies. Journal of Accounting and Finance in Emerging Economies. 2(1), 47-56

Sellami, M. and Fakhfakh, H. (2013). Effects of the mandatory adoption of IFRS on real and accruals-based earnings management: Empirical evidence from France. International Journal of Accounting and Economics Studies, 2(1), 22-33.

Super, S. and Shil, N.C. (2017). Determinants of quality accounting information disclosure. Journal of Accounting and Finance in Emerging Economies. 3(1), 79-86

Van Tendeloo, B. and Vanstraelan, A. (2005). Earnings management under German GAAP versus IFRS. European Accounting Review, 14, 155-180.

Wan Ismail, W. A., Kamarudin, K. A., \& Sarman, S. R. (2015). The quality of earnings in Shariah-compliant companies: evidence from Malaysia. Journal of Islamic Accounting and Business Re-search, 6(1), 19-41.

Watrin, C. and Ullmann, R. (2012). Imrpoving earnings quality: The effect of reporting incentives and accounting standards. Journal of Advances in Accounting, 28(1), 177-188.

Xie, B., Davidson, W. N, III and Dadalt, P.J. (2003). Earnings management and corporate governance: The role of the board and audit committee. Journal of Corporate Finance, 9, 296-316.

Yu, M.D. (2014). Accounting standards and earnings management around the world. Journal of International and Interdisciplinary Business Research, 1, 43-69.

Zenghal, D, Chtourou, S. and Sellami, Y.M. (2011). An analysis of the effect of mandatory adoption of IAS/IFRS on earnings management. Journal of International Accounting, Auditing and Taxation, 20, 61-72. 
Zhang, Y., Uchida, K. and Bu, H. (2013). How do accounting standards and insiders' incentives affect earnings management? Evidence from China. Emerging Markets Review, 16, 79-99.

Zhou, H., Yan Xiong, Y. and Ganguli, G. (2009). Does the adoption of International Financial Reporting Standards restrain earnings management? Evidence from the emerging market. Academy of Accounting and Financial Studies Journal, 13, 43. 